\title{
Doing voices: reading language as craft in black British poetry
}

\author{
Rachael Gilmour, QMUL, February 2014 \\ [final draft post-refereeing] \\ As published in The Fournal of Commonwealth Literature, June 2014.
}

\begin{abstract}
This essay offers a detailed exploration and comparative reading of two poems published twenty years apart: John Agard's "Listen Mr Oxford Don" (1985), and Daljit Nagra's "Kabba Questions the Ontology of Representation, the Catch-22 for 'Black' Writers..." (2007). The former poem is wellknown, being regarded by a range of scholars as the acme of (and often, shorthand for) self-reflexively dialogic black British voice poetry, as it emerged in the 1980s, that plays off the friction between writing and speech. The latter is a complex and satirical take on poetic convention and canonicity including the legacies of 1980s black British poetry - that exploits a tension between written poetic convention and artifice on the one hand, and the idea of the voiced poem as conveying "presence" or "authenticity" on the other. Both poems direct us towards a structuring paradox in which the embodied immediacy of human voice is mediated through the graphic conventions of written poetry. Reading these poems together, the essay considers on the one hand, how ideas about poetic form, language, and voice emerge out of particular historical junctures; and on the other, how such attentiveness to context can help us to develop techniques of a postcolonial "close reading", eschewing totalizing formulae or summative evaluations of linguistic dissidence.
\end{abstract}

Keywords: black British poetry, vernacular poetry, language politics, John Agard, Daljit Nagra, poetic voice.

\section{Craft (n)}

Skill, skilfulness, art; ability in planning or performing, ingenuity in constructing, dexterity. Human skill, art as opposed to nature.

In a bad sense: Skill or art applied to deceive or overreach; deceit, guile, fraud, cunning.

An art, trade, or profession requiring special skill or knowledge.

A small vessel or boat; any sailing or floating vessel. (Oxford English Dictionary)

In the Introduction to his 1985 collection Mangoes and Bullets, titled "Himself Interviews Himself", the poet John Agard considers his role as a "poetsonian":

The whole resurgence of the oral art in poetry has caused black poets to come up with words of their own making. You can think of jazzoetry/Gil Scott-Heron calling himself bluesician or bluesologist/ you also got dub poetry, using reggae beat/ rapso poetry/ \& a number of white poets call themselves ranters. Not that anything is wrong with the word poet. Is just that most people have come to see 'poet' \& 'poetry reading', in very distant cerebral terms. So using these other terms I just mentioned is like subverting the expectations of audiences. Is 
a way of reclaiming other art forms into poetry like theatre \& not treating poetry as isolated. (Agard, 1985: 6)

Agard's particular kind of engagement with orality is evident in his scripting of a written "Introduction" as the transcript of a conversation: an "interview" between "himself" and "himself". In this playful faux-exchange he suggests how poetic voice - here conceived as the "resurgence of the oral art in poetry" - is a product of a specific historical juncture, and emerges out of a particular understanding of the relationship between poet and audience. Agard enacts the kind of demotic border-crossing he advocates by deploying a written "voice" which is both grammatically creolized ("Is a way of reclaiming...", "is just that...") and poetic (the solidus slashes proper to poetry rather than prose) - disrupting the unmarked flow of English prose from two angles. Poetry here, in the hands of the "poetsonian", becomes a craft that can travel between languages and art forms; cross the ocean between the Caribbean, the US and Britain; navigate between sound and form; draw poet and audience together; and carry out offshore raids on prose.

This essay takes as its starting point Agard's invocation of "the resurgence of the oral art in poetry", the importance of voice to black poets in Britain in the 1970s and 80s, and - considered more broadly - how ideas about language, voice, and poetic form emerge from particular historical junctures. Bearing these things in mind, it also asks how we read the language of vernacular poetry, exploring techniques which combine close reading with close listening, to borrow Bernstein's (1998) resonant phrase, to pursue the multivalent and frictive relationship between "graphotext" and "phonotext" (Stewart, 1990), in poetry that seeks to evoke voice through text. These readings focus on a structuring paradox, in which the embodied immediacy of human voice is mediated through the graphic conventions of written poetry. And they consider the particular status of this paradox in black voice poetry, as it negotiates essentializing associations of the racialized voice with an authentic and unreconstructed orality.

Two poems focus this exploration. The first, Agard's "Listen Mr Oxford Don", appears in Mangoes and Bullets, and has been taken by a wide range of critics as the acme of a particular kind of black British voice poetry that plays off the friction between writing and speech, its irreverent and comic dramatization of voice intervening in and disrupting the dominant linguistic order (see for example Crowley, 1996: 51-2; Morris, 1999: 11-12; Vieira, 2000; Sauerberg, 2001: 69; Ramazani, 2001: 15; Ramazani, 2007: 208). The second, Daljit Nagra's "Kabba Questions The Ontology of Representation, the Catch-22 for "Black" Writers....", from his 2007 collection Look We Have Coming To Dover!, also plays comically on the notion of "voice" while exploiting a tension between written poetic convention and artifice on the one hand, and the idea of the voiced poem as conveying "presence" or "authenticity" on the other. Yet, emerging out of different historical junctures, and the latter poem also consciously invoking some of the contexts of the former, they invite very different kinds of laughter, bespeaking very different visions of the relationship between poet, poetic subject, and reader/listener; and ask different questions about the invocation of voice in black - or as Nagra's title has it, "black" - poetry.

Agard's Mangoes and Bullets is a pivotal contribution to what Lauri Ramey has called the "great wave" of black British poetry of the later 1970s and 1980s, involving poets from the Caribbean like Grace Nichols, James Berry, and Jean "Binta" Breeze alongside younger poets who had grown up in Britain such as Linton Kwesi Johnson and Fred D'Aguiar, all of whose poetry works to challenge monolithic notions of British culture, language, and national belonging (Ramey, 2004: 119). Important to many of these poets is experimentation with vernacular and creole language forms; and a concomitant emphasis on orality, voice and sound, as reflected in emerging forms like dub poetry (Marsh, 2005: 
46). As Agard points out in "Himself Interviews Himself", such concerns were shared by black British poets with musician contemporaries, and poets in the Caribbean and the US; and with white British punk-inspired ranter-poets.

The fraught language politics of the period, particularly around issues of race and class, established language as a privileged locus of resistance, and individual and collective self-determination. In black British politics, such a focus on language had been emergent since the founding of the Black Education Movement in the 1960s. By the 1970s and 80s, and in contexts of deepening crisis in British race relations, wider struggles over race and representation were played out through strategic deployments and interpretations of creole languages. Young black people who had known no other home but Britain adopted and adapted creole language forms as modes of cultural identification and resistance to assimilation (Wong, 1986). For the sociologist Dick Hebdige, their "deliberate emphasis of its subversive rhythms" served as "an aggressive assertion of racial and class identities" (Hebdige, 1976: 136). Arguments about assimilation, authenticity and cultural legitimacy, meanwhile, were often routed through language. The hugely influential The Heart of the Race (1985), for example, narrates the genesis of creole languages in the Caribbean as the purposeful creation of "a means of collective self-expression which would defy intimidation."

Through our language we express and define our collective consciousness as a people. Its development has been central to our history and our political experience, for it is through our language that we articulate our reality. (Bryan et al., 1985: 185-6)

Such approaches - resistant assertion of linguistic difference, historical legitimation, even strategic linguistic essentialism - also constitute combative responses to mainstream attitudes to creoles as "jungle talk" (Wong, 1986: 118), lacking in expressive precision, abstraction, and complexity, and often (whether explicitly or implicitly) linked to inchoate fears of crime and disorder. ${ }^{1}$ In The Language Trap, the conservative linguist and educationalist John Honey cast the use of creole languages in Britain as "promoting social divisiveness, aggression and even criminality" (Honey, 1983: 27).

$[T]$ he use of $[\ldots]$ "Black English" is cultivated for the most part among the disaffected young and, at least in present-day Britain, this variety is actually learned as a second language by adolescent blacks (who already speak standard English or one of its regional variants) in order to assert their subgroup's differences from mainstream culture and their scorn for those who identify or collaborate with that culture. Its use is often accompanied by other anti-authority behaviour, including gang membership which is sometimes crime-oriented and involved in drug use; and the creole may be used on occasions specifically in order to irritate and confuse police or other representatives of authority such as teachers or youth club workers who happen to be white. (Honey, 1983: 26)

It is out of this highly racialized field of language politics, and in a wider context of cultural, social, and political marginalization, that black British poetry emerges as an important mode of contestation in the 1970s and 80s, and voice a key term of engagement. As Agard suggests, debates around black poetic language and form revolved around the need to make of poetry a space of collective belonging; to draw together poet and audience in a relationship of engagement and exchange, whether in performance - witness the flourishing of black performance poetry in this period (Habekost, 1993: 2732 ) - or on the page. The use of creoles served as one potential such marker of communal identity and engagement, and at the same time served purposes of legitimation, in a prevailing climate of language activism pitted against linguistic racism. Poets' deployment of creole forms also asserted

\footnotetext{
${ }^{1}$ Evidence of such negative attitudes can be found in the work of left-leaning sociolinguists of the period, whose arguments for the role of creole languages in mainstream education, and emphasis on their expressive potential
} 
them as languages of Britain, appropriate to the expression of new experiences of British exclusion and belonging; challenging the sovereignty of British English synchronically, in maintaining transnational connections to the Caribbean, and diachronically, in language that in its very existence memorializes histories of empire. At the same time, textual representation and manipulation of creole forms necessitates frictions: between hitherto largely unwritten creole forms without orthographic conventions on the one hand, and the highly regulated 'Standard English' conventions of written poetry on the other; as well as between voice and text, or the "'air'/ 'ink' difference", in Garrett Stewart's terms (1990: 5). Thus black British poetry mediates between two ways of thinking about language and voice. On the one hand, the poem as a craft for voice conceived of as immediate and authentic; whether thought of as "embody[ing] the poet's identity", or as the vehicle of "collective consciousness" and longer submerged histories (Marsh, 2005: 46; Bryan et al., 1985: 185). On the other, voice as itself the work of craft, both mediated by and in productive tension with other languages, other voices, as well as the material reality of text itself.

\section{John Agard, "Listen Mr Oxford Don"}

Me not no Oxford don

me a simple immigrant

from Clapham Common

I didn't graduate

I immigrate

But listen Mr Oxford don

I'm a man on de run

and a man on de run

is a dangerous one

I ent have no gun

I ent have no knife

But mugging de Queen's English

Is the story of my life

I dont need no axe

To split/ up yu syntax

I dont need no hammer

To mash/ up yu grammar

I warning you $\mathrm{Mr}$ Oxford Don

I'm a wanted man

and a wanted man

is a dangerous one

Dem accuse me of assault

on de Oxford dictionary/

imagine a concise peaceful man like me/

dem want me serve time

for inciting rhyme to riot

but I tekking it quiet 
down here in Clapham Common

I'm not a violent man Mr Oxford don

I only armed wit mih human breath

but human breath

is a dangerous weapon

So mek dem send one big word after me

I ent serving no jail sentence

I slashing suffix in self-defence

I bashing future wit present tense

And if necessary

I making de Queen's English accessory/to my offence

(Agard, 1985: 44)

The poem's speaker is the unnamed "simple immigrant / from Clapham Common", his silent addressee the "Oxford don" of the title, a cypher who stands as gatekeeper of linguistic, educational, and cultural capital. The poem takes as its intertextual foil the notion of creoles as conceptually insufficient, as well as the image of the black man as criminal. To such as the "Oxford don", the speaker's "simplicity" as much as his criminality may be a self-evident corollary of his language, race, and class; yet these are revealed as knowing poses, increasingly ironized and metaphorized as the poem proceeds. Master of the techne of language ("syntax", "grammar", "suffix", "tense"), the speaker is also a poet, as stanza 6 reveals.

The poem exploits the apparent disjuncture between Standard English and Caribbean creoles, the speaker exploring his relationship to "de Queen's English" in a language creolized at the level of syntax ("Me not no Oxford don") and grammar ("I immigrate"). Creolization is not incidental, but material, to the poem's functions at the levels of rhythm and rhyme. The end-rhymes of "graduate"/ "immigrate", "riot"/ "quiet" depend on a basilectal lack of grammatical marking (instead of standard English "immigrated" and "quietly"), demonstrating not just how rhyme may be provoked to linguistic "riot", but how linguistic "riot" may be crucial to rhyme. They also reveal the phonological and morphological flexibility of a creole continuum, here adapted from the Caribbean into the poetic space of "Clapham Common". In stanza 7, Agard uses the acrolectal or Standard English pronunciation of "breath", with its final fricative; switching from the meso- or basilectal "wit", which precedes it in the same line. When Agard performs the poem, the onomatopoeic power of "breath" becomes the poem's epicentre, voiced as a drawn-out "breathhhhhhhhhhh", the final fricative merging and dispersing into the human breath it denotes, phonology emphasizing a representative rather than arbitrary relationship between sound and meaning (Agard, 2009). The poem's orthography traces a supple movement along a creole continuum: the non-standard "tekking" (stanza 6) as well as "mih human breath" contrasting with the arch, appropriative, acrolectal performance of the final stanza's "making" and "my offence." This code-switching - signalled orthographically in the printed poem, and emphasized in performance - flaunts a creole phonological flexibility that is exploitable for poetic effect.

The poem segues between an acrolectal form identical with conventional written English; and mesoand basilectal forms which are marked orthographically, grammatically, and syntactically. Yet the poem's acrolect is part of a creole continuum, not identical with the English of the "Oxford don", 
however it may appear so; as the poem's voicing reveals. In the second stanza, the word "run" marks this divergence between the text's different soundings: a poetic ear tuned to Caribbean English will hear the full rhyme with "don". Here and elsewhere, the poem issues a call to what Garrett Stewart (1990: 2) terms "silent enunciation."

The poem's orthographic idiosyncrasies work, as Basil Bernstein has said of Amiri Baraka's "AfroAmerican Lyric", "to spur the (silent, atomized) reader into performance", to "insist [... on action" (Bernstein, 1998: 6-7). In so doing, they also draw attention to the complex interplay between speech and writing which is a central feature of the poem. The slashes, for example, are visual markers of poetic writing; and as Mervyn Morris points out, they function typographically "like images of the weapon - the knife, the axe, the hammer, slashing, bashing."

This is especially clear in stanza four, where the double space after the slash suggests the movement of the weapon. The double spaces also focus some irreverent wordplay: mugging the Queen's English, the poem rudely is saying: 'Up yu syntax! Up yu grammar!' (Morris, 1999: 11-12)

Equally, though, these slashes serve as visual markers which impose a tension between the written and sounded text that enhances the rupture sensed by Morris. In connected speech the final consonants of "split" and "mash" elide to the vowel of "up"; the typographic slash, imposing the word boundary qua boundary, abruptly disrupts the flow of speech so that the inner ear hears (or silent enunciation voices) the splitting, the mashing, as well as the highlighted "irreverent wordplay" of "Up yu syntax! Up yu grammar!'”

In this way, the poem dramatizes at the level of form as well as theme the complex push-and-pull, both conflict and collusion, between written and spoken language. Its overarching context is that of a monologic linguistic order problematic on at least three counts. First, its national/racial coordinates: boundaries policed by the gatekeepers of speech ("de Queen's English") and writing ("de Oxford dictionary"). Second, its assumption of language as singular or unitary. And third, its encoded associations of blackness with disorder and criminality, as revealed in the third stanza's escalation from "gun" to "knife" to the unambiguously racially marked "mugging". As Clarke et al. argued in Policing the Crisis, analysing the discourses around the "mugging" scare of 1972-3,

Few would deny that, for all practical purposes, the terms "mugging" and "black crime" are now virtually synonymous. [...] The two are indissolubly linked: each term references the other in both the official and public consciousness. (Clarke et al., 1978: 327)

In its shifting uses and valencies, as traced in Policing the Crisis, "mugging" reveals how language can work to perpetuate, naturalize, and conceal the operations of racial power. In the English against which the poem pits itself, it is the sign that secures to what Paul Gilroy (1987: 88) has called "the syntax of British racism": condensing a range of anxieties onto the figure of the black man as both disruptive to the national order and explanatory of its decline.

Thus the poem dramatizes in order to undermine the structural position of the racialized sign - the "one big word" of the racist state. "I ent serving no jail sentence", says its speaker, with simultaneous juridical and linguistic implication: he will be condemned neither to a jail sentence, nor to serving (writing/speaking) jail sentences. Against a potentially oppressive monologic order, Agard pits doublevoicedness, wordplay, and semantic multiplicity. The poem's speaker is a "mugger": the black subject interpellated as violent and disruptive in a linguistic order that he, simultaneously, violently disrupts. Facetiously, he suggests, he has seized that which does not rightly belong to him - the English language - for his own ends; an act of appropriation that includes the sign "mugging" itself. This (if we turn to "de Oxford dictionary") may be taken to mean not only an assault against person and 
property, but also: learning by hard or concentrated study (the speaker as adept, as well as assailant); and grimacing performative excess (or the possibility of mimicry, in Bhabha's sense). Thus a poem which takes as one of its central objects "de Oxford dictionary" exploits the etymological complexities of English which are that dictionary's central concern. It is precisely "de Oxford dictionary", apparent guarantor of linguistic standardization as well as ethnolinguistic Englishness, that reveals the multivalency of the English sign - as multiple, in fact, as the creole forms against which the poem seemingly sets it - and thus its susceptibility to change and repurposing. "Mugging de Queen's English", then, shows the speaker as trickster, whose adversarial pose conceals a greater depth of engagement with "de Queen's English" than at first appears; while also possessed of linguistic cunning that consists in the capacity to play that language against itself.

In "Listen Mr Oxford Don" the poet's craft is both a remaking and a making. Agard turns conventional poetic form, rhyme, and typography to new ends, while using the oscillation between standard and non-standard grammar and orthography to make the flexibility of a creole continuum materially visible on the written page. At the same time, the poem commits to the power of "human breath" as the foundation of its challenge to monologic orthodoxies, even as it co-opts all the erstwhile signs of linguistic power to its own ends: the written word, "de Queen's English", the "Oxford dictionary," graphic poetic convention, even the word "mugging." Agard's poem is a craft for voice, insisting on its own sounding out, in a compact that draws poetic speaker and reader together against the silent authority of the "Oxford don." Yet in invoking and inviting its own voicing, the poem at the same time subverts associations of the black voice with straightforwardly readable authenticity. Agard uses these associations as a cover for, or foil to, the poem's semantic complexity, that showcases the trickster-like possibilities of creole language in use, and grounds the speaker's triumphant "making de Queen's English accessory/to my offence." As readers we are invited to join and delight in this linguistic subversion, lending voice to the poem and at the same time learning from the poem the radical potential inherent in voice.

The challenges to poetic convention mounted by black British poets like Agard in the 1970s and 1980s had definitive effects. As Nicky Marsh puts it, their work "played an important role in forming a political language capable of articulating new contingencies of identity" (Marsh, 2005: 46). It also achieved a degree of prominence - particularly Agard's poetry, alongside that of Grace Nichols which gave it some purchase in the literary mainstream. When, in 1995, Britain's National Curriculum for English was expanded to include "literature from other cultures and traditions", its list of recommended poets included John Agard (Department for Education, 1995). And when, the following year, the NEAB examination board published their hugely successful Poetry Anthology, its second section, "Poems of Other Cultures and Traditions", included Agard's "Half-Caste" alongside three other poems by black British poets: "Mama Dot" by Fred D'Aguiar, "Wha Fe Call I" by Valerie Bloom, and "For Forest" by Grace Nichols (NEAB, 1996).2 There is an obvious problem with this arrangement, and with the 1995 National Curriculum's vision of national literary culture which it reflects: its consecration of an apparently unified English "literary heritage", to which poets like Agard alongside D'Aguiar, Bloom, and Nichols remain "other" (see Benton, 2000; Dawson, 2009). There is also perhaps another problem specifically in relation to black British poetry, in the Anthology's exclusive emphasis on voice poems by black poets of Caribbean heritage which employ creole language forms. Insofar as the Anthology is in the business of contributing to canon formation, then in respect of black British poetry, it helps to perpetuate not only its "otherness", but also a

${ }^{2}$ Although other UK examination boards also published anthologies to accompany their curricula, the NEAB had the greatest market share nationally $-66 \%$, as reported by Peter Benton in an article in 2000 (Benton, 2000). 
circumscribed view of its formal and stylistic range. As Lauri Ramey (2004) has argued, there are two connected problems with such approaches to black British poetry. The first is a reliance on "an exceedingly limited range of conventional notions regarding what black British poetry should sound and look like and what it should be about" (Ramey, 2004: 120). The second are concomitantly limited sets of assumptions and reading strategies that render poems "accessible' and 'recognisable" at the expense of naive decontextualisation, and stripping them of nuance, double-voicing, or irony (Ramey, 2004: 112).

In the period from the 1980s to the post-millennium, the centre of gravity of British race politics has shifted, yet certain notable continuities remain. Mainstream anxieties which once were focused on African-Caribbean inner-city youth, have diversified, and shifted to other, often newer, immigrant communities. In the realm of language politics, other languages - particularly, South Asian languages - have supplanted Caribbean creole forms in focalizing and making speakable in the realm of language anxieties about national integrity and belonging that have much to do with race, class, and ethnicity. Adrian Blackledge, for example, traces the development of a British political lexicon, particularly since 2001, associating South Asian languages with a range of social ills, including but not limited to "civil disorder, school underachievement, social segregation, societal burden, isolation, unhappy marriage, poor employment prospects, mental health difficulties, lack of social mobility, and threat to democracy, citizenship and nationhood" (Blackledge 2005: vii). What I have called linguistic racism has changed shape, but has by no means disappeared. Yet at the same time, as Stuart Hall (1989; 1991) has argued, the complicated intersections of race, class, and ethnicity, gender and generation, work to trouble notions of black solidarity that might once have seemed more secure. It is in these contexts that we should consider contemporary poetic appeals to notions of the racialized voice.

As the poet Daljit Nagra has himself discussed, his poetry - and particularly his first published collection, Look We Have Coming To Dover! (2007) - acknowledges and interrogates the histories and contexts of British linguistic racism, as it works to dramatize diverse voices within the British Punjabi community, in their subtlety and complexity (Chambers, 2010). Celebrated for his linguistic experimentalism, Nagra has cited the formative influence of Agard alongside other black British poets whose creation of a "distinctly English voice" that destabilizes "standard English" laid much ground for his own work in giving linguistic expression to new and marginalized experiences of living in Britain (Chambers, 2010: 90). Yet in the same interview, he also invokes the racist British television of the 1970s and 80s as a context for his work on poetic voice - "those flat, one-dimensional Peter Sellers-like characters" (Chambers, 2010: 92). On the one hand, those legacies of quasi-comedic linguistic racism ground his poetry's reclamation of British Punjabi voices. On the other, they also gesture to how, as a middle-class, British-born poet, his work probes the risks inherent in poetry that seeks to recreate the racialized voice (Gilmour: forthcoming), and questions the kinds of solidarities such poetry may seem to invite. "Kabba Questions the Ontology of Representation, the Catch 22 for 'Black' Writers...," from Nagra's first collection, is, like Agard's "Listen Mr Oxford Don", a poetic monologue delivered by a speaker whose poetic voice, orthographically, grammatically, and syntactically non-standard, mimes an apparent simplicity which the poem evokes in order to undermine. Like Agard's poem, Nagra's is addressed to a silent pedagogue, Kabba's son's English teacher - on the subject of the composition of the GCSE Poetry Anthology. Yet this far more ambivalent poem charts the distance and explores the space between poet and voice, while troubling the assumption that "silent enunciation" necessarily constitutes an act of solidarity. Playing off the friction between graphotext and phonotext, the poem invites the reader's laughter while asking hard and 
perhaps irresolvable questions about what is at stake in different interpretations of poetic form, language, and voice.

\section{Kabba Questions the Ontology of Representation, the Gatch 22 for "Black" Writers...}

Vy giv my boy

dis freebie of a silky blue

GCSE antology with its three poets

from three parts of Briten - yor HBC

of Eaney, Blake,

Clarke, showing us how

to tink and feel? For Part 2, us

as a bunch of Gunga Dins ju group, "Poems

from Udder Cultures

and Traditions". "Udder" is all

vee are to yoo, to dis cuntry -

"Udder"? To my son's kabbadi posseee, all

yor poets are "Udder"!

Vut free-minding teecher

are yoo to luv "our" poem

ver a goat's neck is cut for blessing

new house. "Our" bastard poet saying such houses

same as Dachau.

My boy, vil he tink ebry new

Barrett-home muslim hav goat blood-party

barbeque? All vee do yoo tink is pray for di curse

of incarnations

as in dat scorpion stinging

"poem", ver di mudder is mantra'd to death?

Dat writer not know vee hav doctors and rocket

rickshaw amblance?

Yoo teachers are like

dis Dalgit-Bulram mickeying

of me as Kabba. I say for di garment

of my voice may be sestina, sonnet, tanka,

tum-ti-tum 
wud best vurds please! A dictation

of the vay I lecture Punjabi to my boy

after school. So vut di coconut do - too shy to uze

his voice, he plot me

as "funny", or a type, even vurse -

so hee is used in British antologies -

he hide in dis whitey "fantum" English, blacked,

to make me sound "poreign"!

In the first section of the poem, Kabba attacks the composition of the GCSE Anthology for its presentation of an apparent British contemporary canon in the triumvirate of Heaney, Blake and Clarke, while other poetry in English is lumped together, made into poetic "Gunga Dins", implicitly positioned as both exotically "other" to and obediently unquestioning of the central assumptions underpinning the Anthology. This he indicts on two counts: its exclusionary vision of national belonging, and its concomitant perpetuation of poetry as rarefied and alienating: "to my son's kabbadi posseee, all / yor poets are 'Udder?" In the second section, he takes particular issue with "'our"” poems, by the Pakistani poet Taufiq Rafat and the Indian poet Nissim Ezekiel - the scare quotes around "our" highlighting these poems' distance from the contemporary British reality of the "Barrett-home muslim". In the final section, Kabba turns on his own poetic creator, conflating him with Bulram (the middle-class, well-educated, snobbishly anglophone schoolteacher narrator from a previous poem) and accusing him of linguistic minstrelsy in pursuit of cheap laughs and/or consecration in "British antologies". Not only does Kabba accuse his creator of playing him for laughs, exploiting the comic associations of an exaggerated South Asian English (see Gilmour, forthcoming); he also indicts the poet for his cynically strategic conformity to prevailing understandings of black poetry as voice poetry.

Kabba's central accusation is of linguistic betrayal: that the poet has given him a "whitey 'fantum' English, blacked, / to make me sound 'poreign'!". His English is shot through with interference from Punjabi at the level of grammar and syntax: the odd missing article ("blessing / new house"), linking verb ("saying such houses / same as Dachau"), verb agreement ("he plot me", "he hide"), or shift in word order ("us / as a bunch of Gunga Dins ju group"). Non-standard orthography also contributes to the poem's sense of voice by marking variant Punjabi English pronunciation ("ebry", "mudder") and lending occasional emphasis ("alll"). Yet in other respects, Kabba speaks a lexically precise, highly idiomatic English that is as distinctively British as it is Indian ("Barrett-home muslim", "freebie", mickeying", "coconut"). This tension between the linguistically exotic and the familiar is at play in the poem's highly stylized "eye vernacular," in which non-standard orthography is amplified so that even non-variant English pronunciations are rendered orthographically distinct: "yor", "teecher", "hav", "uze". This is a strategy familiar from the work of other, earlier black poets whose methods of representing black speech as distinctive include, as Mervyn Morris puts it, "familiar words made up to look peculiar" (Morris, 1999: 47). For the poets of the 1970s and 80s whose work Morris discusses, such as Jean 'Binta' Breeze, such textual tactics may serve to defiantly assert linguistic difference and solidarity. Yet in Nagra's poem, and in the context of Kabba's accusation of exoticization via a "blacked" English, the strategy works differently. Its effect is to highlight the somewhat treacherous artificiality of the poem's "orality", while continuing to play visually on the idea of voice. One result of this is to draw attention to the poem's reliance on sight gags, like the "HBC / Of Eaney, Blake, / Clarke", or the pointedly obscene homophone "cuntry". The poem uses 
orthographic wordplay to make some humorous and evocative connections that rely on the look as well as the sound of words: the arresting homonymic rhyme of "ontology" / "antology" underlining the complex connections evoked in the poem between poetry and the real; as, in a different manner, does the final stanza's "even vurse", with its homophonic play on "verse". The relationship between graphotext and phonotext is charged in Nagra's poem, so that we cannot trust in its apparent "orality" any more than we can be sure whether its witty wordplay (even the transformation of the poet into a "Dalgit") should be ascribed to Kabba or to his creator.

Yet the poem is certainly not a one-sided, comic (if uncomfortable) act of poetic self-accusation. If we need to be careful about lending our voice to the poem lest we collude in an act of racist mimicry, then we also need to be careful about joining with Kabba in his indictment of his poetic creator and his appeal for a different and apparently better kind of poetic "garment / of my voice". For Kabba is an unsubtle reader, prone to just the kinds of generalities and misinterpretations he otherwise condemns. He assumes that his British-born son will relate, if at all, to poetry by South Asian writers, rather than to other poems, including those which reflect on black British life and identity committing, thereby, the kind of reductive move of which he (rightly) accuses the compilers of the Anthology. ${ }^{3}$ He indicts the selection of poems by Rafat and Ezekiel on grounds of exoticism, and maybe he has a point. ${ }^{4}$ But his summaries compound this exoticism by wilfully interpreting both as a kind of social realism, treating "poems from other cultures and traditions" as straightforwardly representational of those "cultures and traditions". He is, in other words, both a critic of the Anthology, and the kind of naïve, reductive reader whom it runs the risk of producing. For example, he readily takes the literary homogeneity of "Briten" at face value, without questioning the relationship of both Clarke and Heaney to this contentious rather than self-evident entity. This absence of reflexivity is underscored when he accuses his creator of "mickeying" (putatively derived etymologically from "Mick", a derogatory term for the Irish), and the accusation of racist, complicit ventriloquism is undercut with the compromised nature of his "own" English. ${ }^{5}$

Kabba's vision of what it would mean to be taken seriously as a poetic speaker is contradictory. On the one hand, he seems to want a faithfully representative voice poetry, one which would follow his "dictation", provide a "garment / of my voice". On the other, he demands a conformity to poetic conventions of form, metre, and register that would lend appropriate cultural legitimacy and, as he sees it, gravitas - "sestina, sonnet, tanka"; "tum-ti-tum / wid best vurds please"; and implicitly disapproves of the vernacular, metrically and syllabically irregular quatrains he has been given. In the former case, legitimacy is afforded through the evoked authenticity of voice, with minimal mediation; in the latter, voice is subordinated to the formal conventions of written poetry. These poetic demands

\footnotetext{
${ }^{3}$ Nagra himself has described his own poetry as influenced by "that first generation of Caribbeans that came over", who "were a bigger influence on me than Indians writing in English."

They were here, writing in Britain, being influenced by the local voice, whereas quite a lot of the Indians - for example Anita Desai, and even V.S. Naipaul - didn't sound British to me. It sounded like the English of certain well-read Indians I knew, who'd come over from India, but people such as LKJ, John Agard and Grace Nichols had a distinctly English voice, they picked up some of the local language of London living, which was the life I was living too. This was also reflected in their phonetic spelling - instead of 'the', they used 'di' or 'da'. I wanted to allude to that voice but reflect an Indian vernacular. The significant thing in both cases is the movement away from 'the': you're still in the tradition of Englishness but with one foot in another practice too. (Chambers, 2010: 90)

4 The Ezekiel poem is "Night of the Scorpion"; yet in typically subtle intertextual mode, Nagra's poem appears to take a linguistic cue from another of Ezekiel's poems, "The Professor": "Visit please my humble residence also / I am living just on opposite house's backside." (Ezekiel, 1989)

${ }^{5}$ The embedding of anti-Irish prejudice in the English language, as well as the ambivalent status of Anglo-Irish poets in the English poetic canon, are recurrent considerations in this collection (Gilmour, forthcoming).
} 
cannot be reconciled; and it is not just this irreconcilability, but also the constraints each places upon what poetry is and does, that constitute yet another "Catch-22 for 'Black' Writers".

Agard's poem and Nagra's reveal their differences in the relationship between graphotext and phonotext, in how and to what end they explore poetic voice and invite their own voicing. Agard's poem is a craft for voice, manipulating the textual conventions of poetry in order to evoke something like presence. Its poetic voice in turn demands readerly participation through "silent enunciation" as a means to flesh out the full range and complexity of its meanings, investing in the power of "human breath" not least as the ground of solidarity between poet, poetic speaker, and reader, the poem's "me" also a "we." Nagra's poem seems, at first sight, to invite us to apply such lessons about black voice poetry to itself; but its invitation to "silent enunciation" leads us somewhere very different, drawing the reader into a seemingly irresolvable conflict between poet and poetic speaker, between different understandings of the nature and purpose of poetic voice, and throwing all notions of poetic identification and solidarity into question. At the same time it seems to suggest that it is craft - the work of artifice, of fabrication - that both subverts notions of "authenticity" in poetry, and vouchsafes its power to overturn easy pieties and ask difficult questions.

Discussions of postcolonial writing, and particularly poetry, often focus on the power of voice, as coterminous with orality, to "usurp" and "decolonize" (Ashcroft, 2009: 142). Yet, while a poem like Agard's may lend itself to such a reading, a poem like Nagra's offers an explicit challenge to its central assumptions. To read each poem attentively necessitates attention to specificity, eschewing totalizing formulae of linguistic dissidence. It also entails reading at different scales simultaneously: recognizing the specific contexts and histories out of which each poem emerges and to which it speaks, as a way to understand how it crafts its meanings at the levels of sound, lexis, and form. What we find thereby is how each instance of "voice poetry" emerges, in actual fact, out of the intersection of multiple voices: the poem's voice or voices, mediated through the graphic conventions of written poetry; the performance of "silent enunciation" in which the reader gives voice to the poem; perhaps, too, the voice or voices of the poem performed by the poet; but also the other voices which surround the poem, sounding like or unlike it - for example, the voices of the mainstream media discussing "mugging," or the voices of other black poets or "poetsonians," or the "Peter Sellers-like" voices of racist mimicry. It is by attending to the poem's evocation of voice in the relation between graphotext and phonotext, and by exploring beyond this, to its dialogic relations with other voices, that we can develop techniques of a postcolonial "close reading" - or "close listening" - that can account properly for the complexities and subtleties of black voice poetry. 


\section{Bibliography}

Agard J (1985) Mangoes and Bullets: Selected and New Poems 1972-1984. London and Sydney: Pluto Press.

Agard J (2009) Listen Mr Oxford Don. In Agard J, Fohn Agard Live! (DVD). In Alternative Anthem: Selected Poems. Northumberland: Bloodaxe.

Ashcroft B (2009) Caliban's Voice: the transformation of English in postcolonial literatures. Abingdon, Oxford and New York: Routledge.

Benton P (2000) The Conveyor Belt Curriculum? Poetry teaching in the secondary school. Oxford Review of Education 26(1): 81-93.

Bernstein B (1998) Introduction. In Basil Bernstein (ed) Close Listening: Poetry and the Performed Word. New York and Oxford: Oxford University Press.

Blackledge A (2005) Discourse and Power in a Multilingual World. Amsterdam and Philadelphia: John Benjamins.

Chambers C (2010) "Meddl[ing] with my type": An interview with Daljit Nagra. Crossings: Fournal of Migration and Culture 1: 87-96.

Clarke J, Critcher C, Hall S, Jefferson T, Roberts B (1978) Policing the Crisis: Mugging, the State, and Law and Order. London: Macmillan.

Crowley T (1996) Language in History: Theories and Texts. London: Routledge.

Dawson E (2009) Re-visioning the National Curriculum at KS3 and 4 and its stipulation to teach literature "from different cultures and traditions". Changing English 16(2): 193-201.

Department for Education (1995) English in the National Curriculum. London: Her Majesty's Stationery Office.

Edwards V (1979) The West Indian language issue in British schools: challenges and responses. London: Routledge and Kegan Paul.

Edwards V (1986) Language in a Black Community. Clevedon: Multilingual Matters.

Ezekiel N (1989) Collected Poems: 1952-1988. New Delhi: Oxford University Press.

Gilmour R (2014 forthcoming) Punning in Punglish, sounding "poreign": Daljit Nagra and the politics of language. Interventions.

Gilroy P (1987) There Ain't No Black in the Union Fack: The Cultural Politics of Race and Nation. London: Hutchinson.

Habekost G (1993) Verbal Riddim: the politics and aesthetics of African-Caribbean Dub Poetry. Amsterdam: Rodopi.

Hall S (1989) New Ethnicities. In Black Film, British Cinema. ICA Documents 7. London: Institute of Contemporary Arts.

Hall S (1991) Old and New Identities, Old and New Ethnicities. In King A D (ed) Culture, Globalization and the World-System. Basingstoke: Macmillan.

Hebdige D (1976) Reggae, Rastas and Rudies. In Hall S and Jefferson T (eds) Resistance Through Rituals: Youth subcultures in post-war Britain. London: Routledge.

Honey J (1983) The Language Trap: race, class and the "standard English" issue in British schools. Middlesex: National Council for Educational Standards. 
Marsh N (2005) "Peddlin Noh Puerile Parchment of Etninicty": Questioning performance in new Black British writing. Wasafiri 45: 46-51.

Morris M (1999) Is English We Speaking: West Indian Literature. In Morris M, Is English We Speaking And Other Essays. Kingston: Randle, pp. 1-16.

Nagra D (2007) Look We Have Coming To Dover! London: Faber.

NEAB (1996) Anthology English and English Literature. London: Heinemann.

Ramazani J (2001) The Hybrid Muse: Postcolonial Poetry in English. Chicago: University of Chicago Press.

Ramazani J (2007) Black British Poetry and the Translocal. In Corcoran N (ed) The Cambridge Companion to Twentieth-Century English Poetry. Cambridge: Cambridge University Press, pp. 200-214.

Ramey L (2004) Contemporary Black British Poetry. In Arana R V and Ramey L (eds) Black British Writing. Basingstoke: Palgrave, pp. 109-136.

Sauerberg L O (2001) Intercultural Voices in Contemporary British Literature: The Implosion of Empire. Basingstoke: Palgrave.

Stewart G (1990) Reading Voices: Literature and the Phonotext. Berkeley, LA, Oxford: University of California Press.

Sutcliffe D (1983) British Black English. London: Blackwell.

Sutcliffe D and Wong A (1986) The Language of the Black Experience: Cultural Expression Through Word and Sound in the Caribbean and Black Britain. London: Blackwell.

Trudgill P (1975) Accent, Dialect and the School. London: Edward Arnold.

Vieira E (2000) Ex-otic-isms on Location: Re-situating the Offshore. In Santaolalla I (ed) "Nere" Exoticisms: Changing Patterns in the Construction of Otherness. Amsterdam: Rodopi.

Wong A (1986) Creole as a Language of Power and Solidarity. In Sutcliffe D and Wong A (eds) The Language of the Black Experience: Cultural Expression Through Word and Sound in the Caribbean and Black Britain. London: Blackwell, pp. 109-122. 